\title{
Procedimentos de construção da imagem do povo e do cineasta em Santo Forte, filme de Eduardo Coutinho
}

\author{
Marina Soler Jorge ${ }^{1}$
}

\begin{abstract}
Resumo
Este artigo procura analisar a imagem do povo no filme Santo Forte, de Eduardo Coutinho. Procuramos mostrar que, a partir dos procedimentos de valorização da imagem do povo, o que temos neste filme é a valorização da imagem do cineasta. Para valorizar a imagem do cineasta, procedimentos diversos serão utilizados: uma aparente naturalidade da entrevista, a transmissão da sensação de "verdade" popular, e a tentativa de mostrar uma intimidade entre entrevistado e entrevistador. As entrevistas, no entanto, quando nos esforçamos para ver que está por trás das aparências mais imediatas de Santo Forte, revelam que o grande personagem deste filme não é o povo, mas o cineasta.
\end{abstract}

Palavras-chave: Imagem do povo, imagem do cineasta, Santo Forte, Eduardo Coutinho

\begin{abstract}
This article intends to analyze the image of the people in Santo Forte, Eduardo Coutinho' film. We will try to show that what we have in this film is the creation of the image of cineaste, instead of a production of the image of the people. To make better the image of the moviemaker, some procedures will be used: an apparent naturalness, the transmission of the sensation of popular "truth", and the attempt to show empathy between interviewed and interviewer. Interviews, however, when in we try to see beyond appearances, reveal that the great personage of this film is not people, but the movie-maker.
\end{abstract}

Keyword: people's image, movie-maker's image, Santo Forte, Eduardo Coutinho.

\footnotetext{
' Marina Soler Jorge é mestre em Sociologia pela Unicamp, doutora em Sociologia pela USP e pós-doutoranda em Sociologia na Unicamp. Este artigo é resultado de pesquisa financiada pela Fapesp - Fundação de Amparo à Pesquisa do Estado de São Paulo.
} 
Eduardo Coutinho é considerado um dos mais importantes documentaristas brasileiros. Com Santo Forte, conseguiu consolidar um estilo que tende a ser elogiado por críticos e pela imprensa em geral. O estilo deste diretor costuma ser elogiado por duas razões principais. Em primeiro lugar, por dar ênfase nas entrevistas com pessoas "comuns" - normalmente pobres ou de classe média baixa, já que são estes que parecem sempre ter algo mais interessante ou emocionante para contar ao espectador médio do cinema brasileiro que em geral não compartilha da vida sofrida dos entrevistados. Nesse sentido, o objeto do documentário de Coutinho em Santo Forte constituise como um objeto de certa forma "esperado" e recorrente entre documentários que abordam questões sociais: pessoas na sociedade que são tidas como incapazes de defenderem-se e falarem por si mesmas (cf. Winston, 1988: 31), necessitando portanto de um interlocutor - o cineasta - para levar suas palavras e sentimentos ao conhecimento público. Um tipo de objeto que contem duas características que, segundo David MacDougall, são fundamentais na capacidade de despertar o interesse e a empatia do espectador pelos personagens "desconhecidos" ou não-mitificados: sua vida absolutamente banal e ordinária e, ao mesmo tempo, uma sensação de que há algo de extraordinário nessa banalidade (cf. MacDougall, 1998). Os personagens de Coutinho em Santo Forte são em grande medida construídos dessa maneira, e disso decorre parte da força de seu estilo baseado em entrevistas que exacerbam esta relação banal/extraordinário dos personagens.

Parte importante do estilo de Coutinho consiste em mostrar o quanto o entrevistado está à vontade com o entrevistador e a equipe de produção - mostrando-se amável, sentimental, aberto, vulnerável, sincero etc. - e também em mostrar o fato de que estamos vendo de fato uma produção - e por isso a ênfase na imagem da câmera, do microfone, dos fios, das pessoas que compõe a equipe e do dinheiro pago aos entrevistados. Mais do reflexividade, este procedimento exacerba, segundo penso, o fato de Coutinho ser o grande personagem de seu filme. Não temos exatamente um filme sobre homens e mulheres do povo, mas um filme sobre um cineasta que se dispõe a subir o morro e a ligar sua câmera diante de pessoas pobres e espiritualizadas. Segundo MacDougall, o cineasta é sempre parte do objeto de seu próprio filme (MacDougall, 1998: 29). O sucesso do objeto e personagem Coutinho é nos dar a impressão de que ele não é o objeto de seu filme, 
e sim os entrevistados, e de que ele obscureceu seu ego para fazer emergir o ego destes, quando o que ocorre é bem diferente: pela maneira através da qual o cineasta coloca em cena a simpatia e a disponibilidade emocional dos entrevistados, suas falas criam, sobretudo, uma imagem poderosa do realizador.

O segundo motivo pelo qual o estilo de Coutinho costuma ser elogiado é sua suposta capacidade de dar acesso aos sentimentos mais intimos dos personagens, por ser capaz de escutar os outros com carinho e nesse processo tirar deles os depoimentos mais verdadeiros e emocionantes possiveis. Considera-se que as pessoas falam a Coutinho coisas que não falariam normalmente. Coutinho é elogiado pelo poder que sua câmera tem de aproximar-se intimamente dos personagens, revelando assim algo da "verdade" e da "realidade" daquele povo filmado. Isso justifica a preferência pela filmagem nas casas dos entrevistados, onde naturalmente há uma maior sensação de que o cineasta está penetrando na intimidade destas pessoas.

Sabemos, no entanto, que a revelação de uma "verdade" ou "realidade" do povo não é uma questão de intenção do cineasta nem da capacidade tecnológica a que chegou o cinema, capaz de gravar o som direto numa entrevista e de nos fazer ver os menores detalhes do rosto humano - o reduto da identificação tão fundamental na experiência do espectador (MacDougall, 1998: 51). A "realidade" ou a "verdade" de uma imagem é uma construção social e temporal: "Não importa o quanto nós sintamos a necessidade de un testemunho objetivo da realidade, nossas tecnologias de produção da imagem não providenciarão isso para nós' (Ruby, 1988: 309).

A sensação de "verdade" no cinema decorre de uma elaboração filmica, de escolhas que são feitas no processo de produção - ou seja, a "verdade" não é un dado da realidade social, mas um empreendimento, que também depende da disposição do espectador. É por isso que temos "verdades" tão diversas, como as construidas pelo Cinema Direto dos irmãos Mayles - aproximando-se idéia do cinema como "mosca na parede" - e pelo Cinema Verdade de Jean Rouch e Edgar Morin adeptos da idéia da "mosca na sopa". Coutinho também é um eximio construtor de "verdades", e é assim que é tido pelo público e pela crítica em geral: sua "verdade" residiria em sua habilidade de mostrar e de dar voz ao povo, sem imposições. Procuraremos mostrar aqui como se constrói filmicamente este mecanismo de aproximação de uma suposta 
"verdade" popular em Santo Forte.

A primeira imagem que veremos é um plano estático de um casal. Eles olham para a câmera, como se posassem para uma fotografia. Diversos personagens serão introduzidos desta maneira, que lhes instaura ao mesmo tempo um aspecto de dignidade, objetividade e respeito. Estaríamos vendo os personagens da forma que são, como num "retrato", como se o realizador quisesse mostrá-los da maneira mais verdadeira possível, sem intervenções. Além disso, há uma sensação de que desta maneira eles se mostram a si mesmos, de que eles se apresentam para nós, sem a mediação do cineasta. Há, portanto, nestes quadros imóveis que "apresentam" os personagens durante todo o filme, um desejo de transmitir a sensação de verdade e de deferência para com aqueles homens e mulheres do povo filmados.

$\mathrm{O}$ fato de este quadro ser a primeira seqüência do filme pode também nos transmitir a sensação de que a palavra do povo será a primeira e a mais importante a aparecer na tela, antes mesmo da palavra do cineasta, como se este fosse um simples veículo para a transmissão da voz popular. Com efeito, Coutinho, além de nos deixar ver logo no começo de seu filme o "retrato" do povo, logo nos deixará ouvir sua voz, sem mediações: a próxima seqüência será de André (o homem do casal que vemos na tela) falando. Há, naturalmente, um certo impacto nesta seqüência tão "popular": dar a voz ao povo é a primeira coisa que se faz, logo depois deste ser apresentado de uma maneira também sui generis (não há locução dizendo "este é André e sua esposa" e coisa do tipo). Ainda não temos os créditos iniciais, não temos o nome do filme, não temos a voz do narrador, mas já temos a imagem e a voz do povo.

Eduardo Coutinho lança mão o tempo todo de uma estratégia poderosa: parecer alguém isento e desprovido de julgamentos, comprometido com a voz do povo; mas ao mesmo tempo procurando corroborar aquilo que seus entrevistados disseram, o que faz com que nos sintamos mais próximos deles e mais emocionados com suas palavras. Da união desta suposta "verdade da imagem" com a suposta "verdade do povo", transmitida através do sentimento de aceitação de seu discurso, teremos a estratégia principal de Coutinho e aquilo que dá força a seu estilo. O povo aqui é construído para que pareça mais verdadeiro e muito mais interessante aos olhos do espectador.

André começa a falar sobre a pomba-gira que baixava no espírito 
de sua esposa e que dizia querer matá-lo. Diz que pede para a mulher se tratar do problema dela com os espíritos, caso contrário lhe avisa que o casamento corre perigo. A fala de André é cheia de entonações, gesticulada, interessante. Mais à frente, em outro momento do filme, com André ainda sendo entrevistado, a câmera deixará um espaço do lado esquerdo de André enquanto ele reproduz sua conversa com a falecida mãe, de modo que quase enxergamos o espírito dela sentado a seu lado. Com esse e os demais recursos, o cineasta cria um poderoso ambiente de aceitação do que o entrevistado diz, de modo a transmitir uma sensação de respeito. Mas logo ouviremos a primeira intervenção do cineasta na entrevista, primeiramente elaborando uma pergunta para que André esclareça o modo como um espírito repleto de boas intenções tratou de sua mulher médium: Coutinho diz: "Fez a limpeza como?". André the responde. Mais algumas falas do entrevistado e nova intervenção de Coutinho: "É como se você estivesse falando com três pessoas?". Agora, mais do que perguntar, Coutinho aqui procura dar uma direção à fala do entrevistado, de modo que consiga extrair aquilo que é mais interessante para seu documentário. Na verdade, o cineasta incentivou o entrevistado a dizer aquilo que seria mais interessante para o filme: era como se houvesse três pessoas conversando com André. Parece um artificio natural, visto tratar-se de um filme baseado $\mathrm{em}$ entrevistas: em certos momentos o entrevistador deve "dar corda" ao entrevistado, de modo que a conversa nào esmoreça. Para criar o sentimento de "verdade" e "naturalidade" do estilo Coutinho, e para transmitir e a sensação de que sua câmera consegue "penetrar na alma humana", não basta simplesmente ligar a câmera e dar voz ao povo, mas fazê-lo falar conforme se espera que ele fale. Desta maneira, o espectador pode identificar-se com o personagem de Coutinho e com a sensação de respeito ao povo transmitida na sua relação com os personagens.

A fala de Coutinho não apenas dá corda para o entrevistado, mas colabora para construir uma imagem deste entrevistado como alguém pertencente ao universo popular. Quando André termina sua fala - é essa a impressão que temos dada a "naturalidade" dos cortes de, mas naturalmente é a montagem do filme que interrompe a fala de André procurando nos transmitir uma sensação de naturalidade, como se o entrevistado tivesse dito tudo aquilo que queria antes de ser interrompido - temos a contextualização temporal e espacial do filme 
que veremos: uma tela preta nos anuncia que estamos no Rio de Janeiro no dia 3 de outubro de 1997. A próxima imagem introduz um dado novo neste local e nesta data: nesse dia o Papa João Paulo II estava no Brasil e rezava uma missa perante uma multidão de fiéis no Aterro do Flamengo. Está dada, portanto, uma qualificação temporal que serve de pano de fundo ao filme: colher depoimentos sobre a religião entre homens e mulheres do povo durante a visita do Papa ao Brasil.

Afirmar que o cineasta estabelece uma relação assimétrica com as pessoas por ele filmadas pode soar como banal e primária, como se revelasse apenas o óbvio já sabido e reconhecido por grande parte dos espectadores de documentários. Enquanto assistimos a documentários, porém, parece que nos esquecemos disso. O reconhecimento da assimetria não nos impede de ter uma visão positivista, como se o cinema documental ele desse acesso imediato a uma parte da "realidade". Por isso, apesar de reconhecermos como fato a relacçao assimétrica entre entrevistador e entrevistado, continuamos vendo um cineasta como Eduardo Coutinho - e tantos outros - como alguém que consegue transmitir um aspecto da "realidade" popular.

A assimetria se revela claramente, a meu ver, no momento em que Thereza, a entrevistada, é questionada sobre se é feliz. Ela esboçará um meio termo, dizendo que por um lado é feliz, mas por outro não. Coutinho insiste na pergunta, indagando-lhe o porquê, ao que Thereza pergunta: "Eu preciso responder a essa pergunta?". Durante todo o filme, a relação assimétrica estará presente mas será evitada pelo cineasta, que pretende sugerir que desempenha uma função próxima a um "amigo" para aqueles entrevistados. A presença de Coutinho é fundamental pra despertar certas opiniões dos entrevistados, assim como a presença do Papa é fundamental para despertar o sentimento católico que eles manifestam.

Em relação à Igreja Católica, isso logo se revela no depoimento de Braulino, justamente um dos que parecem ser dos mais "orgulhosos" em relação a sua condição de umbandista. Coutinho lhe pergunta o porquê dele estar gravando em fita de vídeo cassete a missa do Papa, ao que ele responde, sem muito entusiasmo e desconversando: "eu sou católico...". O cineasta não percebe que Braulino não quer muita conversa naquele momento e continua perguntando a Braulino quais são os espíritos que ele incorpora. Braulino então diz que não quer conversar sobre isso naquele momento e os espectadores, que 
provavelmente pertencem ao mesmo universo cultural de Coutinho, podem não entender de imediato o porquê de Braulino ter desconversado. Perto do final do filme isso será esclarecido: Braulino não queria falar da umbanda na "frente" do Papa. Deve ter achado desrespeitoso e, mais do que isso, deve ter achado de certa forma temerário. A "gafe" de Coutinho mostra um pouco da separação entre ele e os entrevistados já que, para o diretor, assim como para a maioria dos espectadores, a Igreja Católica talvez não seja algo a ser "temida". Já os entrevistados demonstram, na frente de Coutinho, um profundo respeito e parecem temer ao Deus católico. No entanto o que queremos sugerir aqui é que essas demonstrações de respeito à Igreja Católica na frente de Coutinho ocorrem com tal intensidade justamente pela presença do cineasta que, para aqueles moradores do morro, ocupa, no espectro da estratificação social, posição de "outro" exatamente como o catolicismo.

O cineasta, porém, parece não perceber a importância de sua presença para despertar certas opiniões. Se percebe, não colocou esta discussão no filme. Parece que vemos uma tentativa intensa de respeitar a opinião do povo, como se aqueles depoimentos tivessem algo de sagrado, como se a voz do povo nos revelassem uma sabedoria inigualável. E não vemos indicação alguma que o cineasta e a equipe se dêem conta de que os depoimentos que eles obtém estão determinados pela presença de Coutinho, pela posição social que este ocupa em relação aos depoentes, e pelo fato deles estarem munidos do equipamento cinematográfico. Seria fundamental e interessante discutir esse aspecto, sem o qual a possibilidade de dar "voz ao povo" fica reificada numa relação fetichista dada pelo entrevistador e sua câmera. Autores como Jay Ruby consideram a reflexividade uma obrigação ética e estética do realizador para com seu objeto: é preciso mostrar não apenas o produto (o filme), mas também o produtor e o processo que levou a sua elaboração (cf. Ruby, 1988). No caso de Santo Forte seria fundamental, de acordo com aqueles autores que consideram a importância da reflexividade, apresentar justamente o processo de construção da imagem do popular sincrético e o papel do produtor na construção dessa imagem. Os planos em que vemos a equipe de Coutinho não são, naturalmente, suficientes para isso, nem o fato de vermos o pagamento aos entrevistados. Estamos acostumados a observar câmeras em nosso cotidiano, e programas comerciais da televisão paga e aberta já nos dão acesso à visão do equipamento de cinema e da própria equipe. 
Observar as pessoas que compõe a produção de um filme no próprio filme não nos causa mais nenhuma estranheza e não me parece suficiente para uma discussão sobre a própria produção cinematográfica.

As imagens da equipe, porém, tem algo importante que não podemos deixar passar, e que já nos sugere o verdadeiro foco deste documentário: a centralidade do próprio Coutinho. Esta centralidade, naturalmente, não diz respeito apenas ao fato de ele estar sendo mostrado como o líder de um séqüito que o acompanha, ou ao fato de ouvirmos sua voz ou vermos sua imagem de relance algumas vezes. A imagem central de Coutinho em meio à equipe é apenas um pequeno indício do fato de que é o cineasta e seu "estilo", na verdade, o verdadeiro objeto fílmico. O importante é atentarmos para o cineasta ser, a todo o momento, o pólo imantador das entrevistas, e para o fato de que ele consegue, às vezes mais às vezes menos sutilmente, levar a entrevista para o caminho que deseja, criando assim uma idéia de popular que tem no cineasta sua própria referência. Além de ouvirmos sua voz, percebemos que o entrevistado olha, durante as entrevistas, o tempo todo para Coutinho, como se esquecesse que lá existe uma câmera de cinema. $O$ fato de os entrevistados não olharem para a câmera nos remete a um efeito de "naturalidade", como se eles falassem espontaneamente para o cineasta, como se se esquecessem de toda a equipe e a parafernália cinematográfica que lá está, como se conversassem com um amigo. Desta forma, mostrar a parafernália apenas reforça o sentimento de naturalidade e amizade conquistado por Coutinho: tem-se a sensação de que mesmo diante de toda a equipe que estamos vendo, o entrevistador sente-se absolutamente natural e aberto enquanto conversa com o cineasta.

Naturalmente, uma tal presença do cineasta faz com que ele se torne o principal objeto de seu filme, apesar da temática popular/ religiosa que informa o conteúdo mais aparente. É o um tipo de cinema em que o cineasta é quem aparece, e não exatamente os entrevistados. Como escreve Paulo Menezes: 'em um filme quem dá primeiro o seu depoimento é o cineasta e não os personagens das histórias, por mais reais que elas sejam' (Menezes, 1994: 123). Em Santo Forte, temos um filme cujo desenvolvimento acaba ocultando esta relação, dotandoa de uma aparência de espontaneidade. A assimetria e o lugar ocupado pelo popular e pela equipe de filmagem seria um aspecto interessante a ser explorado no próprio filme Santo Forte, e não algo a ser obscurecido 
pelos numerosos procedimentos que visam nos causar a impressão de que estamos vendo e ouvindo a voz do povo a respeito de sua religião. Coutinho é efetivamente o personagem de seu filme, como o norteamericano Michael Moore é dos seus, evidentemente sob um outro aspecto.

Em Santo Forte há uma tentativa sutil mas eficaz de estabelecer, com as intervenções do cineasta, uma espécie de hierarquia entre as religiões na qual as religiões afro-brasileiras ocupam um papel mais elevado, provavelmente por seu caráter mais imediatamente popular aos olhos de parte da camada erudita a quem se dirige o filme. A Igreja Católica e a Universal do Reino de Deus também são, naturalmente, populares, no sentido de que têm uma ressonância e uma presença no povo, conforme podemos ver no próprio Santo Forte. Mas as religiões afro-brasileiras parecem ser, no filme, mais autenticamente populares, ligadas às "raizes" do povo brasileiro afro-descendente. Ao falar sobre a verossimilhança no documentário, Elizabeth Cowie diz que o pobre 'precisa aparecer adequadamente pobre de maneira que a audiência possa reconhecer a pobreza' (Cowie, 1999: 30). Podemos dizer que, em Santo Forte, o personagem popular precisa aparecer como tal no sentido de que os espectadores possam reconhecer nele uma suposta autenticidade e originalidade daquilo que é tido como "do povo", assim como algum aspecto curioso que os transforme em um tema atraente. Temos aqui, respectivamente, desempenhando estas funções, a religiosidade afro-brasileira e o sincretismo religioso.

O realizador procura, com algumas de suas intervenções, reforçar esse caráter popular das religiões afro-brasileiras, o que faz com que ele, da mesma forma, procure qualificar positivamente as manifestações paranormais que the são associadas. Isso ocorre na medida em que Coutinho verbaliza sua empolgação com os relatos das religiões afrobrasileiras, e intervém com perguntas para que o entrevistado recubra seu depoimento com um caráter de veracidade irresistível. À esposa de Braulino ele pergunta, um tanto deslumbrado com a figura do homem que parece, em si mesmo, o personagem que ele diz incorporar: "E ele fala com aquela voz de preto velho?". Pergunta à médium Thereza: "A senhora teve outras vidas? Conta para mim"; "A senhora acha que está pagando um pouco os pecados da rainha (que ela diz ter sido em outra vida)?". Pergunta para André, depois que ele conta o encontro com a falecida mãe, de modo a reforçar o impacto de seu depoimento: "Você 
chorava? Ela chorava?". Para Dejair, visando esclarecer o aspecto eminentemente popular da umbanda, depois que ele esclarece a hierarquia do espiritismo afro-brasileiro: "E você acha que tudo isso aí tema ver com a África?". Para Carla, quando ela diz que quem der mais compra a proteção de um exu: "E você acha que o mundo é assim?"; "Você não tem medo de que a Maria Padilha (pomba-gira) se vingue de você?". A resposta a estas indagações estão, naturalmente, dadas pelas próprias perguntas de Coutinho. O entrevistador não visa adquirir alguma informação nova, mas reforçar uma imagem do homem e mulher do povo que deseja transmitir.

O discurso dos médiuns, dos umbandistas e dos que convivem com as manifestações espíritas têm, no geral, uma representação positiva. O mesmo não ocorre com as opiniões a respeito da Igreja Universal ou das Igrejas Evangélicas em geral, provavelmente consideradas menos dignas de serem vistas como autenticamente populares.

Veremos depoimentos que criticam explicitamente a Igreja Universal. Dejair critica o fato de a Igreja Universal falar 136 constantemente no diabo, e diz que na umbanda o "coisa-ruim" só é invocado em determinados momentos. Segundo ele, se você não quer a presença do diabo, não deve chamá-lo tão frequentemente como se faz na Universal. Taninha, outro entrevistado, será estimulado por Coutinho a falar mal desta Igreja: "Como é que eles (os espíritos) baixam na Universal?", ao que o homem começa a criticar o ritual de "descarrego" e todo o escândalo promovido pelo pastor. Logo no começo do filme, quando o Papa está na televisão, uma senhora fala mal da Igreja Universal por ter criticado a vinda do Papa ao Brasil. Sua fala é entrecortada pela voz do próprio Coutinho que faz perguntas para que ela esclareça o teor de sua crítica: "O povo (da Universal) não critica o Papa que veio aqui?! Um homem que não faz mal a ninguém, que veio aqui dar a benção para todo mundo...Teve gente da Universal que criticou ele por ele ter vindo aqui...". Enquanto ela fala, Coutinho permanece questionando-a para que ela continue falando e explicite do que se trata: "Quem criticou?", "Por que critica?", "Eles falam o que?" e coisas do tipo.

Além da crítica direta à Igreja Universal do Reino de Deus, os personagens são estimulados a falar da umbanda, e parece haver sempre um certo deslumbramento com as experiências que os entrevistados 
relatam. Quando se trata da Universal, porém, isso não acontece. Alex, por exemplo, nos é mostrado como um adepto da umbanda. Vemos imagens, que a própria equipe de Coutinho fez, do batizado de sua filha num terreiro. Pais e mães de santo balançam o bebê e cantam músicas típicas das religiões afro-brasileiras. Ficamos sabendo, o que pode causar certa surpresa, que a água benta foi fornecida por un padre da Igreja Católica que, segundo Alex, não se importou com o batizado no terreiro, já que a menina havia sido batizada na Igreja Católica antes. Alex diz: "Eu sempre coloquei na minha cabeça que o mais importante é a Igreja Católica. Não existe religião para mim, e sim a Igreja Católica. Eu não sigo a ela, não vou aos domingos em missas, mas eu acredito muito". O sincretismo de Alex torna-se ainda mais radical quando ouvimos sua mãe, freqüentadora da Igreja Universal, nos informar que o próprio Alex, umbandista praticante e católico quando convém, freqüentou a Universal do Reino de Deus com o objetivo de curar-se de alguns problemas de saúde, que segundo ela o estavam quase matando (afirmação estranha pois ele é jovem, forte, e aparenta ser muito saudável). Coutinho quer saber de Alex se ele ficou bom depois disso, e ele confirma que sim. Segundo o rapaz, o pastor fez um gesto com a mão e ele saiu de lá bon no mesmo instante. O cineasta intervém novamente e "pergunta": "Como é que você explica, você acha que tendo fé qualquer coisa pode acontecer?". Um tipo de pergunta que, como já dissemos, contém em si a própria resposta, que será aquela dada efetivamente por Alex: "Eu acho que o que aconteceu lá foi uma fé muito grande".

Porque o cineasta não pergunta ao próprio Alex sobre a ida dele à Igreja Universal do Reino de Deus? Porque coloca sua mãe para falar, ela que inclusive só aparece nesse momento e que nos causa a impressão, inclusive pela sua maneira de falar, que é uma seguidora menos sincrética da Igreja? Penso que Coutinho não nos mostra diretamente Alex dizendo "bem, um dia eu tive um problema de saúde e fui na Universal e lá eles fazem um trabalho muito bom, fui curado completamente etc" pois isso, de alguma forma, macularia sua imagem de umbandista, e portanto seu aspecto eminentemente popular. O filme coloca a mãe para nos contar essa história. Quando a imagem volta para Alex a pergunta de Coutinho sobre o que aconteceu na Universal procura excluir a possibilidade de a cura ter sido efetuada pelo poder do pastor ou da Igreja em si mesma. A cura é devida ao próprio Alex 
através de sua fé, e por isso a preocupação tão grande do entrevistador de colocá-la nestes termos, conduzindo a própria resposta do rapaz, de modo que não haja risco de ele elogiar diretamente o trabalho que é feito na Universal.

A entrevista de Thereza é provavelmente aquela na qual melhor se revela o deslumbramento do filme pelo universo das religiões afrobrasileiras. As perguntas iniciais já são colocadas no sentido de fazer a senhora falar de sua relação também íntima, mas num sentido agora amigável, com os espíritos. "O que são essas pulseiras no seu braço?"; "Como é que a senhoras cuida deles (dos guias espirituais)?". Em seguida, uma pergunta para nos fazer simpatizar com a própria entrevistada, e assim estarmos mais receptivos ao que ela vai contar: "A senhora criou seis filhos sozinha?". Ela, como muitas das entrevistadas, teve um marido imprestável e acabou se virando sozinha na criação da quase sempre numerosa prole. Thereza parece ser um personagem que por si só já desperta empatia, como uma "vovó" sofrida e simpática. Mas o discurso de Santo Forte é cuidadosamente elaborado para exacerbar essa sua característica. Não é a toa que é ela quem 138 aparece no centro do pôster do filme e que é dela a frase colocada no centro deste: "Os espíritos estão em toda a parte. Aqui mesmo tem uma legião, agora mesmo. É que a gente não tem vidência para ver". Ela é, segundo penso, um personagem que condensa as características populares e religiosas que o cineasta gostaria de reforçar com seu filme: uma senhora sorridente e amável, com uma vida difícil, com uma espécie de simplicidade que consegue emocionar, que tem uma crença profunda nos espíritos e dotada de uma mediunidade poderosa (vê e ouve os espíritos e também os incorpora). Ela conversa de maneira aberta com Coutinho, o que ajuda a transmitir a sensação de "naturalidade" e de respeito responsável pelos elogios efusivos que acompanham o cinema deste realizador.

Thereza se deslumbra com aquilo que é próprio de uma classe mais alta do mesmo modo que Santo Forte se deslumbra com o universo da religiosidade afro-brasileira. Enquanto o cineasta sobe o morro procurando por aquilo que acredita ser "autêntico" no povo, Thereza desce todos os dias para trabalhar e lá adquire uma espécie de admiração por aquilo que é menos popular e mais "sofisticado" mesmo no interior de sua religião. Pode-se dizer que Coutinho e Thereza efetuam o movimento contrário, não apenas em termos espaciais mas também 
“ideológicos", demonstrando admiração por aquilo pertence a um universo cultural diferente do seu. E isso é importante para despertar o sentimento de simpatia que é tão próprio dela, já que, ao mesmo tempo em que ela é caracterizada como eminentemente popular, também nos mostra um gosto inexplicável pela cultura erudita (que ela naturalmente identifica com as camadas sociais mais favorecidas). Esse gosto surpreendente lhe dá um aspecto mais interessante - afinal, é espantoso que uma senhora tão humilde diga gostar de Beethoven.

Não é apenas Thereza que procura, com seu discurso, aproximarse de um mundo que não é o seu. Se Thereza diz que, de alguma forma, tem uma relação de pertencimento com o mundo da cultura erudita dado pelas suas vidas passadas, Braulino, também médium, diz ter uma relação de proximidade com o mundo dos endinheirados. Braulino, assim como Thereza, também é médium de incorporação, e dirá que é muito bajulado, "e não por pessoas humildes". Um de seus guias, Brás Carneiro, foi escravo na casa grande, e por isso estabeleceu relações próximas com os senhores. Braulino diz que, quando incorpora esse seu guia, sente que o que Brás Carneiro foi, ele, Braulino, também é. $\mathrm{E}$ daí se deduz a razão pela qual ele, Braulino, é bajulado por pessoas de, nas suas palavras, "alto poder aquisitivo". É interessante como Braulino fala com orgulho dessa sua relação com pessoas mais ricas, feliz por, de alguma forma, reproduzir no presente a relação de proximidade entre dominantes e dominados ao estilo Casa Grande \& Senzala.

Depoimentos interessantes e reveladores como esses - quando uma relação entre classes se expressa a partir da relação entre entrevistador e entrevistado - vem e vão, mas, ao prender-se a um "estilo" baseado exclusivamente na sua habilidade como entrevistador, Coutinho deixa de investigar ou mesmo de observar com maior profundidade muitas das sugestões levantadas pelas próprias entrevistas que ele instigou. O resultado é uma espécie de "naturalismo" bem construido, no qual temos a impressão de que as coisas se sucedem da maneira mais "verdadeira" possivel na frente da câmera, mas pobre na investigação. "Deixar" que as pessoas falem - ou fazer tudo para que as pessoas pareçam falar com espontaneidade - é parte inalienável do estilo executado pelo diretor. Mas, ao contrário do que muito se diz sobre seus filmes, pouco revela de uma natureza humana e popular daqueles entrevistados, pois estabelece uma relação fetichizada com a palavra que, além da estar ela mesma reificada como instrumento de 
investigação popular, foi incentivada pelo realizador e registrada com a sua presença sem que no entanto nada disso tenha sido colocado em questão pelo filme. Temos aqui o problema da falta da reflexividade, a que nos referimos anteriormente. Além disso, sabemos que "deixar as pessoas falarem" ou "deixar as imagens falarem", ou ainda, como coloca Weber em relação à ciência, "deixar os fatos falarem", constitui-se numa tomada de posição, e uma tomada de posição um tanto "desleal", pois é uma atitude que procura convencer num certo sentido enquanto se oculta o lugar de onde se fala (Weber, 2005: 35).

Em outras palavras, pouco ou nada do que estamos discorrendo aqui é discutido no filme, apesar de estar tudo mais ou menos claro, provavelmente até pelo realizador, que em algumas entrevistas para revistas deixa transparecer uma visão mais provocadora do modo de construção de suas imagens populares. Há apenas uma menção, no filme, ao processo fílmico de construção das imagens e da palavra do popular, e que, segundo penso, tem sido supervalorizada enquanto medida reflexiva: a explicitação de que eles recebem dinheiro para se deixarem filmar. As seqüências nas quais vemos uma profissional da 140 equipe de Coutinho pagando aos entrevistados visa, segundo penso, alertar para um procedimento documental que normalmente fica escondido por trás da "naturalidade". das entrevistas, ou seja, para o fato que tudo aquilo tem menos de "natural" do que parece, já que deve ter havido ao menos uma negociação mínima a respeito dos direitos de imagem e da quantia que seria paga aos entrevistados em razão do uso destas imagens. Mas Santo Forte é um filme tão crente na "naturalidade" que constrói que essa tentativa de radicalização do discurso documental soa tímida. Mais do que tímida, da maneira que é colocada, apenas visa reforçar todas essas sensações descritas, ao nos mostrar o pagamento como uma espécie de necessidade contratual que não abalaria a maneira aberta, sincera e natural a partir da qual os entrevistados hipoteticamente se expõem para a equipe. $O$ fato de a equipe pagar aos entrevistados depois da entrevista também funciona para diluir um pouco a impressão de uma relação comercial, tendo em vista que, se víssemos o dinheiro sendo pago antes, o comércio ficaria muito mais explícito.

Da primeira vez que vemos a moça da equipe de Coutinho pagando um entrevistado, esse entrevistado será Lídia, uma senhora que também descobriu que podia receber espíritos quando era jovem. 
Segundo ela, seu pai não aceitaria seu dom, e um médium mais experiente "amarrou" os espíritos que queriam trabalhar com ela. Lídia hoje se diz cristã. Vemos, com ela, um sincretismo à revelia, enquanto diversos outros personagens mostram-se completamente à vontade com seu sincretismo.

Então, num dado momento, numa altura do filme na qual já nos acostumamos com o desenrolar da entrevistas, construídas para parecerem o mais naturais e espontâneas possíveis, surpreendemo-nos com algo inédito até então neste filme: a moça da equipe de Coutinho que paga trinta reais a Lídia pela entrevista concedida. Ela esboça uma recusa pouco convincente, dizendo que "para dar testemunho da palavra de Deus" não precisa de dinheiro, mas logo aceita o pagamento e muda de assunto, dizendo que quando o filme ficar pronto ela vai querer assisti-lo, e engatando uma nova conversa com a equipe. Tudo continua da mesma forma que antes, como se nenhum elemento novo na relação entre entrevistado e entrevistador tivesse sido inserido. Pelo contrário, ela engata uma nova conversa, o que nos dá a sensação de que está absolutamente à vontade. O momento em que se explicita o pagamento de Lídia também é colocado "naturalmente", como uma decorrência lógica e "natural" deste filme repleto de estratégias para demonstrar que "respeita" seus entrevistados.

Além disso, existe aqui o papel da moça da equipe de produção que, falando suavemente, explica o porquê do pagamento: ele é devido ao fato de que a equipe está fazendo um filme e o exibirá nos cinemas, sendo portanto justo que o entrevistado receba um certo dinheiro pelo trabalho prestado na confecção do filme. Ao enfatizar a idéia de "justiça", o "estilo" Coutinho está salvo, já que são ele e sua equipe os responsáveis pela promoção desta justa remuneração em troca da entrevista realizada. Ao invés de exacerbar um modo de produção documental assimétrico, a imagem da compra do depoimento apenas reforça o aspecto de "respeito ao povo" e de espontaneidade que o filme quer passar.

Outras imagens de entrevistados sendo pagos serão exibidas. Taninha recebe trinta reais em notas de um real (temos a impressão de que ele pediu para receber o dinheiro trocado) e Braulino aparece lendo o termo de cessão de imagem, o que implicitamente remete ao pagamento. É interessante notar que após cada uma dessas imagens de pagamento pela entrevista, haverá uma pequena seqüência que 
restabelece a idéia da amizade e espontaneidade, de modo a desfazer qualquer impressão de que aquela relação que se estabeleceu entre entrevistador e entrevistado tenha sido uma relação eminentemente comercial. Taninha e a moça da equipe que lhe paga divertem-se com o fato de ela lhe dar o dinheiro em notas de um real. Braulino pega um copo de cerveja e brinda junto com a equipe de Coutinho. É claro que não há problema algum em se tomar uma cerveja com o entrevistado, mas colocar isso no filme tem implicações imediatas na leitura que fará o espectador. Portanto, a meu ver, em Santo Forte, ao invés de propiciar alguma discussão sobre os procedimentos documentais, mostrar os entrevistados sendo pagos acaba por reforçar a imagem do popular criado por Santo Forte e o próprio "estilo" criado pelo cineasta. Ou seja, acaba por recolocar a imagem de um popular verdadeiro, aberto, generoso e hospitaleiro, e também funciona de modo a nos sugerir um Coutinho intimo e respeitoso em relação a esse popular, como se ele e sua equipe estivessem sendo efetivamente aceitos no seio da comunidade entrevistada e, por um momento, fazendo parte desse universo popular. Mostrar, como faz Santo Forte, o pagamento ao 142 entrevistado e a assinatura do termo de cessão de imagens funciona não tanto, a meu ver, para levantar uma discussão sobre a questão ética que paira na exploração da imagem do entrevistado, mas para resolvê-la no filme, de forma que a sensação de respeito e de intimidade na relação entre equipe e entrevistado permaneça.

Diversos procedimentos reforçarão a idéia de intimidade entre Coutinho e as pessoas entrevistadas. Mostrar Thereza oferecendo cafezinho à equipe, entrar na sua casa na noite de Natal e filmar seus netinhos dormindo, mostrar Quinha conversando espontaneamente com alguém da equipe de Coutinho enquanto ela acredita estar em off, filmar a entrega das fotos realizadas pela equipe para os personagens fotografados, além da já citada cervejinha - imagem extrema da cumplicidade entre o povo e a equipe de Coutinho - são procedimentos que visam aproximar o lado erudito, representado pelo realizador, do lado popular, representado por aquela comunidade. As diferenças entre eles permanecem, pois não há no filme exatamente uma idéia de identidade entre equipe e entrevistados, como se ambos estivessem do mesmo lado da estrutura social. O que existe é uma sensação, eficientemente construída ao longo do filme, de que as fronteiras entre o cineasta e o povo tornam-se mais suaves e adocicadas graças 
justamente ao papel do realizador em parecer que faz aflorar o lado sincero, humano e aberto das pessoas daquela comunidade. Assim, ao fazer com que o espectador acredite que está "dando a voz ao povo" $\mathrm{e}$ mostrando- the a beleza simples da maneira popular de lidar com o mundo, o cineasta na verdade está construindo una visão de si próprio e auto-conferindo a si mesmo a imagem daquele que justamente tem a habilidade de catalizar toda a espontaneidade popular. Por isso em Santo Forte a imagem do povo é apenas secundária - ela serve de suporte, segundo penso, à imagem do próprio realizador e à construção de seu "estilo".

Existe outra forma de aproximação que talvez seja a mais forte no sentido de criar a sensação de intimidade e aceitação na relação entre realizador e entrevistado. Trata-se das várias seqüências nas quais vemos os personagens cantando. Logo no começo do filme, um homem canta timidamente junto com Roberto Carlos na missa do Papa. Uma mocinha canta em seguida de maneira bem mais desinibida, levando inclusive as mãos ao alto enquanto acompanha o "Rei".

Entre os personagens que ocuparão mais tempo do filme, Alex, Braulino, André (com a esposa) e Thereza cantam. Coutinho parece gostar muito das imagens dos entrevistados cantando, tanto que elas aparecem en quase todos os seus filmes. É fácil entender por que. Ora, cantar na frente de desconhecidos (a equipe cinematográfica) e deixarse gravar por uma câmera de cinema enquanto se canta é sinal inequívoco da proximidade que Coutinho mostra ter conseguido com seus populares, já que é algo que exige, para a maioria das pessoas que não canta profissionalmente, uma boa dose de desinibição. Ao mostrar seus personagens cantando, o cineasta nos dá a impressão de que conseguiu fazer com que eles se revelassem totalmente para a câmera, de maneira aberta e desinibida.

$\mathrm{O}$ aspecto da aproximação e da intimidade é deveras importante para a eficácia de Santo Forte, tanto que o filme se encaminha para o final aumentando o tom de cumplicidade que foi sendo formado ao longo da produção. É 24 de dezembro, véspera de Natal - uma data por si reveladora de uma intimidade adquirida - e Coutinho entrevista Thereza agora perguntando não dos espiritos que ela recebe, mas querendo saber sobre o dia que ela passou, como um bom e velho amigo faria. E, ao final, ela insiste para que ele entre na sua casa e veja seus netos dormindo. A câmera percorre o quarto e encontra um pequeno 
altar no qual Thereza presta homenagens a "Vovó Cambina", um espírito que ela incorpora. É com essa imagem que Coutinho encerra seu filme, enquanto a trilha sonora capta o som ambiente - um rádio ou cd ligado - de modo, mais uma vez, a reforçar, desta vez pelo som direto, a "naturalidade" e a "verdade" do que está sendo filmado.

Como visto, portanto, estamos diante de um filme que, segundo a análise aqui empreendida, esforça-se por construir uma visão de popular a partir de suas práticas religiosas sincréticas, utilizando-se de procedimentos que procuram sugerir uma aproximação afetiva e respeitosa com o povo. O principal deles, que domina o filme, é, sem dúvida, a entrevista: planos americanos nos quais os entrevistados contam experiências religiosas para o realizador e, adicionalmente, relatam outros aspectos particulares de suas vidas. As entrevistas, no entanto, quando nos esforçamos para ver que está por trás das aparências mais imediatas de Santo Forte, revelam que o grande personagem aqui não é o povo, mas o cineasta.

\section{Bibliografia citada}

CowIE, Elizabeth. The spectacle of actuality. In: Gaines, Jane, (org.), Renov, Michael (org.). Collecting Visible Evidence. Minneapolis: University of Minnesota Press, 1999.

MacDougall, David. The fate of the cinema subjet. In: Transcultural Cinema. Princeton, New Jersey: Princeton University Press, 1998.

Menezes, Paulo Roberto Arruda de. A questão do herói-sujeito em cabra marcado para morrer, filme de Eduardo Coutinho. Tempo Social. São Paulo, vol. 6, n. 1-2, 1994.

RuBY, Jay. The ethics of imagemaking; or, "They're going to put me in the movies. They're going to make a big star out of me...". In: Rosenthal, Alan (org). New challenges for documentary. Berkeley: University of California, 1988.

Weber, Max. A ciência como vocação. In: Ciência e Politica, duas vocações. São Paulo: Cultrix, 2005.

Winston, Brian. Documentary: I think we are in trouble. In: Rosenthal, Alan (org): New challenges for documentary, Berkeley: University of California, 1988. 